\title{
The role of thoracic trauma in inflammatory responses, apoptosis and bacterial translocation following multiple traumas
}

\author{
Erhan Ayan, M.D., ${ }^{1}$ Oğuz Koksel, M.D., ${ }^{1}$ Ayşe Polat, M.D., ${ }^{2}$ Lülüfer Tamer, M.D., ${ }^{3}$ \\ Gülden Ersöz, M.D., ${ }^{4}$ Murat Demir, M.D., ${ }^{1}$ Hatice Yıldırım Yaroğlu, M.D., ${ }^{3}$ \\ Alper Akdağ, M.D., ${ }^{4}$ Ali Özdülger, M.D., ${ }^{1}$ Sema Erden, M.D. ${ }^{5}$ \\ ${ }^{1}$ Department of Thoracic Surgery, Mersin University Faculty of Medicine, Training and Research Hospital, Mersin \\ ${ }^{2}$ Department of Pathology, Mersin University Faculty of Medicine, Training and Research Hospital, Mersin \\ ${ }^{3}$ Department of Biochemistry, Mersin University Faculty of Medicine, Training and Research Hospital, Mersin \\ ${ }^{4}$ Department of Infectious Disease, Mersin University Faculty of Medicine, Training and Research Hospital, Mersin \\ ${ }^{5}$ Health Occupation High School, Biostatistics, Mersin
}

\begin{abstract}
BACKGROUND: Blunt chest trauma and its complications are commonly encountered in emergency medicine. Herein, we used a rat model to investigate the role of thoracic trauma in inflammation, apoptosis and bacterial translocation following multiple traumas.

METHODS: Ninety Wistar rats were divided equally into nine groups. Rats underwent a standardized blunt thoracic and/or head trauma and were sacrificed 24 or 48 hours after the trauma. Specimens from various organs and blood samples were collected and quantitatively cultured for aerobic organisms. Interleukins, TNF- $\alpha$, and MCP-I levels were assessed in the sera and markers of apoptosis were detected in the lungs.

RESULTS: Levels of interleukins, TNF- $\alpha$ and MCP-I in all of the groups undergoing trauma were significantly higher than those of the control group $(p=0.001)$. Levels of apoptotic cells in the groups undergoing head and thoracic trauma (HTT) were significantly higher than those of the control group $(p=0.009)$. Light microscopic evaluation indicated that damage in the HTT groups was significantly higher than that in the control group. The incidence of bacterial translocation was also significantly higher in the HTT groups $(p=0.003)$.
\end{abstract}

CONCLUSION: Multiple inflammatory mediators are activated in multiple traumas (including blunt thoracic trauma), which allow bacterial translocation and apoptotic processes to occur. Our results indicate that thoracic trauma plays a major role in post-traumatic bacterial translocation, inflammation, and apoptosis following multiple traumas.

Key words: Head trauma; interleukin; lung injury; systemic inflammatory response syndrome; thoracic trauma.

\section{INTRODUCTION}

Blunt traumas and their associated complications are major causes of death in young and middle-aged people. Previous

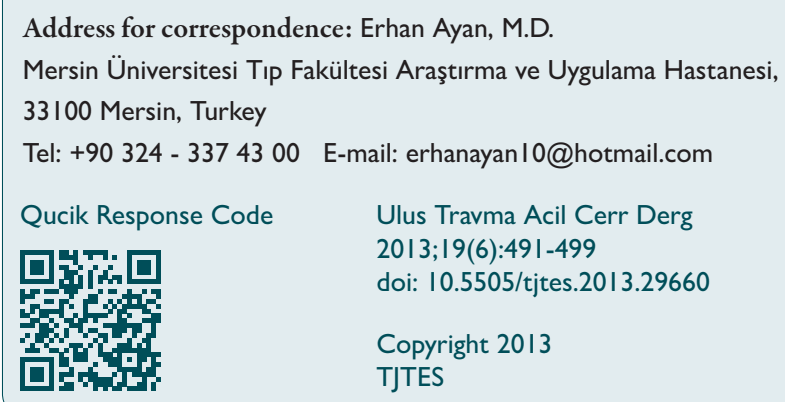

studies have reported that acute lung injury (ALI) associated with pulmonary contusion, sepsis and multiple organ failure (MOF) are major complications of blunt trauma that can lead to morbidity and mortality. Approximately one-third of trauma cases presenting at hospitals present with thoracic trauma. Lung contusion resulting from thoracic injury plays an important role in the development of ALI and Acute Respiratory Distress Syndrome (ARDS). It has been reported that ALI can lead to the development of MOF, and that morbidity and mortality are significantly higher in blunt trauma cases with lung injury than those in traumas without. ${ }^{[1,2]}$ Studies using an experimental thoracic trauma model have shown that an acute inflammatory response develops shortly after the trauma, but this response subsides with time, returning to normal levels within approximately 7 days. Because of these 
results, it has been hypothesized that the change in inflammatory response alone is not sufficient to explain the etiology of complications like ALI and ARDS, and that additional processes that might trigger the development of these pathologies should be investigated. Furthermore, it was noted that apoptosis following thoracic traumas may be associated with the inflammatory response. ${ }^{[3-6]}$

Bacterial translocation refers to the spread of bacteria and their products in the intestinal flora to solid organs, which can be due to intestinal hypoperfusion, burns and stress. Bacterial translocation has been cited as one of the leading factors in the development of acute lung injury, MOF and sepsis. [7-10] We undertook the current study to determine whether there was a correlation between the cellular and humoral inflammatory responses, apoptosis and bacterial translocation in a model of lung contusion developed after blunt thoracic trauma and/or multiple traumas accompanied by blunt thoracic trauma. We also aimed to determine the effects of blunt thoracic trauma in the development of the aforementioned processes.

\section{MATERIALS AND METHODS}

All experiments were performed in accordance with the $\mathrm{Na}$ tional Institutes of Health Guidelines on the Care and Use of Laboratory Animals. The approval of the Ethics Committee was obtained before the onset of the study. This study was approved by the Mersin University Institutional Ethics Committee for Animal Studies with document number 26.12.2007/I 3 and was funded by the Mersin University Scientific Research Projects unit.

In this study, 90 Wistar rats were equally divided into nine groups as follows: (C; control, C24; control sacrificed 24 hours after first anesthesia, C48; control sacrificed 48 hours after first anesthesia, TT24; thoracic trauma and sacrificed 24 hours after trauma, TT48; thoracic trauma and sacrificed 48 hours after trauma, HT24; head trauma and sacrificed 24 hours after trauma, HT48; head trauma and sacrificed 48 hours after trauma, HTT24; thoracic and head trauma and sacrificed 24 hours after trauma, HTT48; thoracic and head trauma and sacrificed 48 hours after trauma.

For twenty-four hours prior to trauma, the animals were given standard rat chow as well as water containing 80,000 $\mathrm{cfu} / \mathrm{mL}$ E.coli. In all of the groups, anesthesia was given as $25 \mathrm{mg} / \mathrm{kg}$-I thiopental sodium (Pental Sodyum, I.E. Ulugay, Turkey) before trauma. Only the control group (Group C) received anesthesia without any trauma. The thoracic trauma groups (Group TT) were exposed to thoracic trauma using the mechanism published by Raghavendran et al. with a force of $2.7 \mathrm{~J}$ followed by anesthesia. ${ }^{[4]}$ In the head trauma groups (Group HT), severe head trauma was created according to the method described by Foda et al. ${ }^{[1]}$ Sequential thoracic and head traumas were created in the same manner as mentioned above in the groups receiving thoracic and head traumas (Group HTT). Twenty four or 48 hours after the trauma, the rats were anesthetized and the chest cavities were opened. The animals were euthanized by cardiac blood aspiration.

Following sacrifice at 24 and 48 hours, multiple specimens were taken from the rats' mesenteric lymph nodes, spleen, liver, lungs and ileum, and blood samples were collected and evaluated for bacterial growth in corresponding $5 \%$ blood agar. In the blood, interleukin - I beta (IL-I $\beta)$, interleukin- I0 (IL-I0), interleukin-4 (IL-4), tumor necrosis factor alpha (TNF $\alpha$ ), and monocyte chemoattractant protein-I (MCP-I) were evaluated, while apoptosis was assessed in the lung.

In the first 30 minutes after trauma, we noted a reduction in the rats' movements and food intake. After two hours, the rats regained normal movements. The food and liquid consumption of the rats that underwent trauma was $50 \%$ less than that of the control groups.

\section{Evaluation of the Bacterial Translocation}

Blood samples ( I mL each) were incubated aerobically for 48 hours at $37 \circ \mathrm{C}$ in $5 \mathrm{~mL}$ of triptych soy broth and plated on triptych soy agar with $5 \%$ blood plates. Liver, spleen, mesenteric lymph nodes and lung were extracted, weighed separately, and placed in sterile grinding tubes. The samples were homogenized with I $\mathrm{ml}$ of triptych soy broth using sterile ground glass stoppers. After grinding (Pottere S, Biolab, Melcungen-Germany), $500 \mu \mathrm{L}$ of homogenate was transferred into a tube containing $4.5 \mathrm{~mL}$ of $0.9 \% \mathrm{NaCl}$ and was used to perform four serial dilutions. The final dilution was 10-4. From this dilution, $100-\mu \mathrm{L}$ aliquots were plated onto tyriptic soy agar plates with 5\% blood and EMB agar plates. Quantitative culture results were determined with the following formula [(number of colony-forming units (CFU) $x$ reciprocal of dilution $\times 10) /$ weight of tissue]. ${ }^{[12]}$ Finally, the terminal ileal loop was excised and placed in a tube of thioglycollate broth to determine indigenous bacteria. To prevent contamination of the environment, these cultures were prepared as indicated in the previous procedure. All agar plates and thioglycollate broth tubes were incubated aerobically in $5 \% \mathrm{CO}_{2}$ for 24 hours at $37^{\circ} \mathrm{C}$. We did not study obligate anaerobes, because these organisms are rare causes of translocation. ${ }^{[13]}$ The gram negative enteric organisms were identified by biochemical profiles, staphylococcus was identified by the catalase test and the tube coagulase test, and Enterococcus was identified by esculin hydrolysis in the presence of bile and was grown in broth containing $6.5 \% \mathrm{NaCl}$.

\section{Histopathological Evaluation}

Tissue samples were taken from the most traumatized part of the left lung, immersed in 10\% buffered formalin and embedded in paraffin using a standard procedure. Serial sections from paraffin-embedded tissues were deparaffinized in $x y-$ 
lene, dehydrated through graded concentrations of ethanol, and evaluated following haematoxylin and eosin staining. Microscopic evaluations were performed by a single pathologist who was unaware of the characteristics or treatment of the animals.

\section{TUNNEL (Terminal Deoxynucleotidyl Transferase Mediated dUTP Nick-End Labeling) Method}

The TUNNEL method (in situ Apoptosis Detection Kit, Biogen, USA) was used to investigate apoptosis in lung tissue. After being deparaffinized and rehydrated, sections were pretreated with proteinase $\mathrm{K}$ for 15 minutes at room temperature, and then endogenous peroxidase activity was quenched with $2 \% \mathrm{H}_{2} \mathrm{O}_{2}$. Slices were then incubated at $37{ }^{\circ} \mathrm{C}$ for 60 min with $50 \mu$ of TdT buffer. Finally, the reaction was visualized colorimetrically with a streptavidin-biotin- peroxidase complex and diaminobenzidine. TUNNEL labeled slides were counterstained with I\% methyl green.

\section{Morphological Analysis}

Light microscopic analyses of hematoxylin and eosin stained slides of lung specimens were evaluated with regards to pulmonary architecture, tissue edema formation, polymorphonuclear leukocyte infiltration and alveolar hemorrhage using a modified method by Koksel et al. ${ }^{[14]}$ Lung injury was scored 0 to 3 as follows: $0=$ normal histology; $I=a$ few inflammatory cells in alveolar spaces; 2 = perivascular mild edema formation, moderate inflammatory cell infiltration, focal hemorrhage and partial destruction of pulmonary architecture, 3 = severe edema and dense inflammatory cell infiltration, marked hemorrhage and complete destruction of pulmonary architecture.

To numerically evaluate the density of apoptotic cells in the lung sections, the total number of dark brown stained (TUNNEL positive) nuclei (alveolar epithelium and endothelial) were counted in 10 randomly selected high power fields (10x400) with light microscopy.

\section{Biochemical Evaluation}

MCP-I, TNF- $\alpha$, IL-I $\beta$, IL-4 and IL-I0 levels were detected using BioSource Immunoassay kits (Rat MCP-I catalog no:KRCI0I2, Rat TNF- $\alpha$ catalog no: KRC30II, Rat IL-I $\beta$ catalog no:KRC00 I I, Rat IL-4 catalog no:KRC0042, Rat IL-I0 catalog no:KRCOI0I; Biosource International, Camarillo, CA).

The BioSource kit is a solid phase sandwich Enzyme LinkedImmuno-Sorbent Assay (ELISA). A specific antibody coats the wells of the provided microtiter strips. Samples, standards, and control specimens are pipetted into these wells, followed by the addition of a biotinylated secondary antibody. During the first incubation, the specific antigen (MCP-I, TNF- $\alpha$, IL-I $\beta$, IL-4, IL-I0) binds simultaneously to the immobilized antibody on one site, and to the solution phase biotinylated antibody on a second site. After removal of excess secondary antibody, Streptavidin-Peroxidase is added, which binds to the biotinylated antibody to complete the four member sandwich. After a second incubation and washing to remove the unbound enzyme, a substrate solution is added, which reacts with the bound enzyme to produce color. The intensity of this colored product is read at $450 \mathrm{~nm}$, and the intensity of the color is directly proportional to the concentration of sample present in the original specimen (as compared to a standard).

\section{Statistical Analyses}

A one-sample Kolmogorov-Smirnov test was used to determine whether serum cytokine levels were normally distributed. All of the variables were normally distributed. A one-way ANOVA was used to detect variations in variables among the groups. Tukey Post Hoc Tests were used for pair wise comparisons. The relationships between categorical variables were determined by chi-square analyses using the SPSS II.5 software program. Correlation coefficients were determined with Microsoft Excel.

\section{RESULTS}

\section{Survival and Gross Morphology of Lung Contusion Injury}

Marked hemorrhage and pulmonary contusion were observed ventrally and dorsally in both lungs in all of the rats exposed to thoracic trauma (Figure I). Within the first 30 minutes following trauma, 3 rats in the head trauma $(\mathrm{HT})$ group and 4 rats in the thoracic trauma (TT) group died and

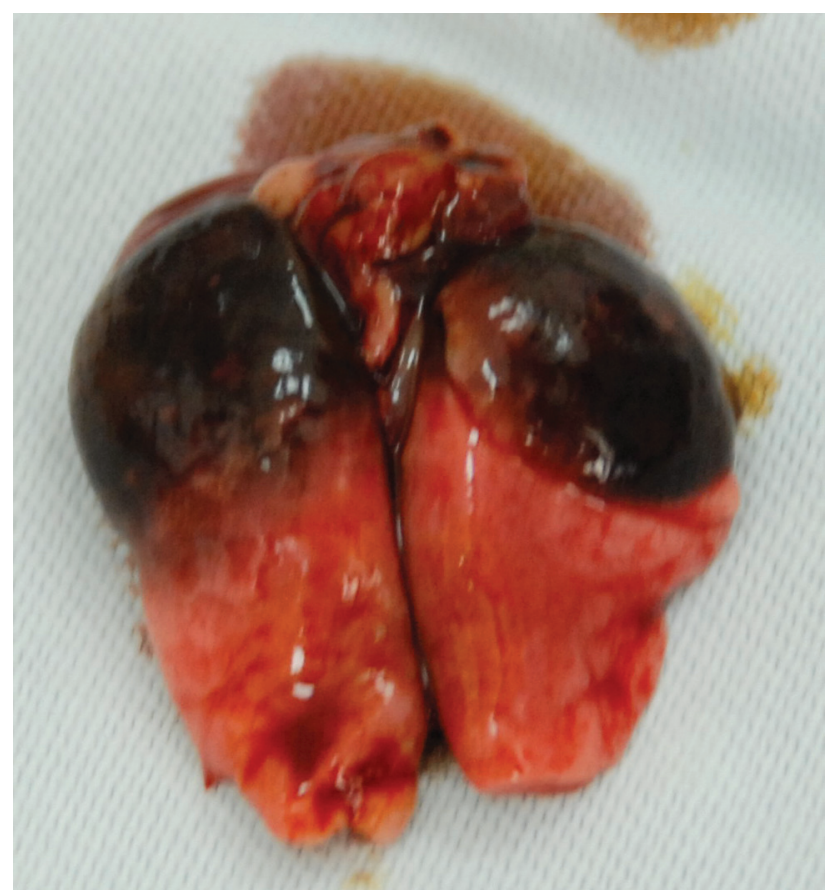

Figure 1. Macroscopic appearance. The bilateral upper lobes present significant contusion. 
were excluded from the study. Rats were added to both of these groups to replace those that died and corresponding traumas were repeated. Of the three rats that died in the HT group, 2 had epistaxis, while the other had no marked macroscopic signs. An evaluation of the 4 rats that died in the TT group showed that 3 of them had massive hemothorax while other rat was observed to have cardiac tamponade.

Serious dyspnea developed in all of the groups that were subjected to trauma, and the rats remained motionless for an hour following the trauma. Dyspnea regressed after the first six hours, while motor movements remained mostly unchanged. At 12 hours, the rats were motile in their cages, and at 24 hours they showed a marked increase in motility and a decrease in dyspnea. No treatment or oxygen support was given to the rats during this observation process. All of the rats that were exposed to thoracic trauma had macroscopic contusion.

\section{Serum Cytokine Levels}

Biochemical data pertinent to all groups are presented in Table I.

\section{Interleukin-1ß}

At 24 and 48 hours after the trauma, IL- I $\beta$ was significantly higher in all of the trauma groups than in the control group $(p=0.000)$. There were no significant differences between the trauma groups. At 48 hours, values in the head and thoracic trauma (HTT) group were significantly higher than those in the HT and TT groups. When values in the trauma groups at 24 and 48 hours were compared with one another, only the HTT group showed an increase in the values at 48 hours, relative to those at 24 hours $(p<0.05)$; there was no significant difference in the values of the other groups.

\section{Interleukin-10}

Values of IL- 10 in the TT and HTT groups at 24 and 48 hours after trauma were significantly higher than those of the $C$ and
HT groups $(p=0.000)$. No significant difference was found between the $\mathrm{C}$ and HT groups. IL- 10 values in the HTT group at 48 hours were significantly higher than those in the TT group at that time point $(p<0.05)$. There was a significant increase in the values of the HTT group at 48 hours relative to the values at 24 hours. This difference was not significant in any of the other groups.

\section{Interleukin-4}

IL-4 values in the HT and HTT groups at 24 hours following trauma were higher than those in the $C$ group $(p=0.000)$. The IL-4 values of the TT group were not significantly different from those of the C group. IL-4 values in the TT and HTT groups at 48 hours were significantly higher than those of the $\mathrm{C}$ group. IL-4 values in the HTT group were significantly higher than those in the HT group $(p<0.01)$. There was no significant difference between the HT and $C$ groups at 48 hours.

\section{TNF- $\alpha$}

Although TNF- $\alpha$ levels in the TT and HTT groups were higher than those of the $C$ group at 24 hours $(p=0.000)$, this difference was not significant. TNF- $\alpha$ values in the TT and HTT groups at 24 hours were significantly higher than those of the HT group at 24 hours. The TNF- $\alpha$ levels of all of the trauma groups were significantly higher at 48 hours relative to the control values $(p=0.000-0.003)$, although there were no differences between the trauma groups.

\section{MCP-1}

MCP-I was significantly higher in all of the trauma groups in comparison to the $C$ group at 24 and 48 hours $(p=0.000)$, although there were no differences in these values between the trauma groups.

\section{Bacterial Translocation (BT)}

Any bacterial growth in the solid organs (i.e., liver, spleen,

Table I. Serum cytokine levels of all groups

\begin{tabular}{|c|c|c|c|c|c|c|c|c|c|c|}
\hline Groups & $\begin{array}{c}\text { IL-I } \beta \\
(\mathrm{pg} / \mathrm{ml})\end{array}$ & $\begin{array}{l}\text { Statistical } \\
\text { Significance }\end{array}$ & $\begin{array}{c}\text { IL-4 } \\
(\mathrm{pg} / \mathrm{ml})\end{array}$ & $\begin{array}{l}\text { Statistical } \\
\text { Significance }\end{array}$ & $\begin{array}{c}\text { IL- } 10 \\
(\mathrm{pg} / \mathrm{ml})\end{array}$ & $\begin{array}{l}\text { Statistical } \\
\text { Significance }\end{array}$ & $\begin{array}{c}\text { TNF- } \alpha \\
(\mathrm{pg} / \mathrm{ml})\end{array}$ & $\begin{array}{l}\text { Statistical } \\
\text { Significance }\end{array}$ & $\begin{array}{l}\text { MCP-I } \\
(\mathrm{pg} / \mathrm{ml})\end{array}$ & $\begin{array}{l}\text { Statistical } \\
\text { Significance }\end{array}$ \\
\hline$C-0$ & $108.59 \pm 5.06$ & & $22.47 \pm 4.50$ & & $26.15 \pm 2.89$ & & $59.35 \pm 7.70$ & & $192.31 \pm 25.08$ & \\
\hline C - 24 & $105.78 \pm 5.26$ & $*$ & $23.45 \pm 5.17$ & $*$ & $21.32 \pm 4.01$ & $*$ & $50.97 \pm 5.04$ & $*$ & $203.58 \pm 27.02$ & $*$ \\
\hline HT - 24 & $170.88 \pm 27.39$ & $*_{p}<0.001$ & $31.80 \pm 7.09$ & $*_{p}<0.01$ & $16.43 \pm 3.37$ & n.s. & $96.45 \pm 14.80$ & ${ }^{*} p<0.001$ & $283.08 \pm 46.60$ & ${ }^{*} p<0.001$ \\
\hline TT - 24 & $192.94 \pm 50.36$ & $*_{p}<0.001$ & $28.18 \pm 2.20$ & n.s. & $33.76 \pm 6.81$ & $* p<0.001$ & $249.48 \pm 37.25$ & $*_{p}<0.001$ & $293.32 \pm 18.38$ & $* p<0.001$ \\
\hline HTT - 24 & $189.33 \pm 28.84$ & $*_{p}<0.001$ & $33.70 \pm 5.44$ & $*_{p}<0.001$ & $37.39 \pm 8.05$ & $*_{p}<0.001$ & $237.61 \pm 62.18$ & $*_{p}<0.001$ & $289.16 \pm 17.16$ & $*_{p}<0.001$ \\
\hline C - 48 & $114.78 \pm 8.05$ & $* *$ & $22.47 \pm 4.50$ & $* *$ & $26.15 \pm 2.89$ & $* *$ & $59.35 \pm 7.70$ & $* *$ & $192.31 \pm 25.08$ & $* *$ \\
\hline HT - 48 & $171.45 \pm 32.94$ & $* * p<0.001$ & $31.11 \pm 5.82$ & $* * p<0.01$ & $26.67 \pm 4.95$ & n.s. & $213.54 \pm 68.03$ & $* * p<0.05$ & $307.90 \pm 41.45$ & $* * p<0.001$ \\
\hline TT - 48 & $182.18 \pm 29.65$ & $* * p<0.001$ & $35.76 \pm 5.79$ & n.s. & $42.38 \pm 6.58$ & $* * p<0.001$ & $231.66 \pm 5.79$ & $* * p<0.001$ & $293.76 \pm 28.18$ & $* * p<0.001$ \\
\hline HTT - 48 & $239.03 \pm 48.10$ & $* * p<0.001$ & $39.82 \pm 6.09$ & $* * p<0.001$ & $50.59 \pm 7.14$ & $* * p<0.001$ & $237.20 \pm 77.04$ & $* * p<0.001$ & $312.16 \pm 27.17$ & $* * p<0.001$ \\
\hline
\end{tabular}

(C-0: Control Group time 0, C-24: Control Group 24th hour, C-48: Control Group 48th hour, HT-24: Head Trauma Group 24th hour, HT-48: Head Trauma Group 48th hour, TT-24: Thoracic Trauma Group 24th hour, TT-48: Thoracic Trauma Group 48th hour, HTT-24: Head and Thoracic Trauma Group 24th hour, HTT-48: Head and Thoracic Trauma 48th hour.) Cytokine levels were compared using a pair-wise comparison. For each cytokine, the results of the 24th hour trauma group were compared with the result of $C$ - 24. Similarly, for each cytokine, the results of the 48th hour trauma group were compared with the result of $C-48$. Statistical significance levels ( $p$ values) are given in the column next to each cytokine. (n.s.: not statistically significant according to pair-wise comparison). 


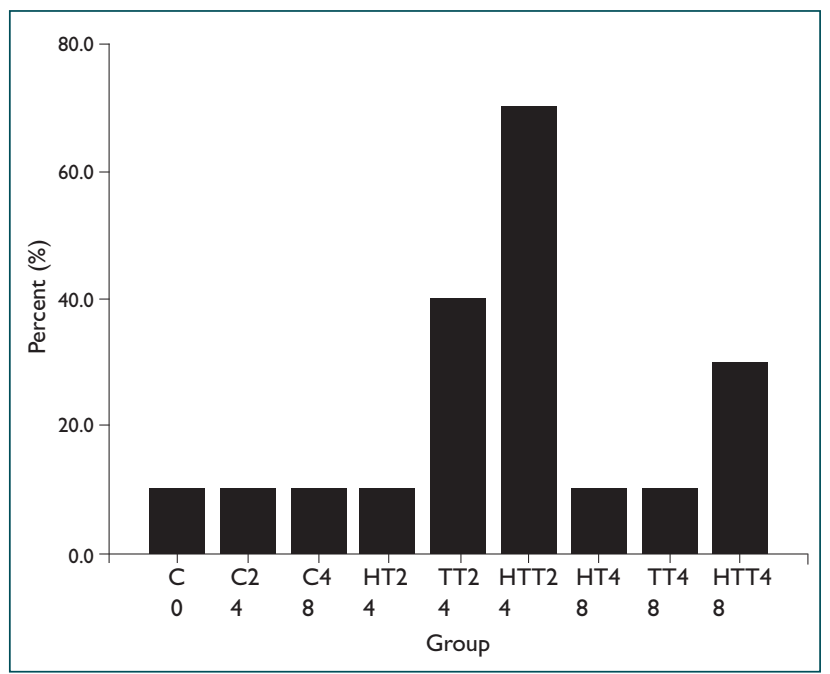

Figure 2. Bacterial growth in solid organs. (C-0: Control Group time 0, C-24: Control Group 24th hour, C-48: Control Group 48th hour, HT-24: Head Trauma Group 24th hour, HT-48: Head Trauma Group 48th hour, TT24: Thoracic Trauma Group 24th hour, TT-48: Thoracic Trauma Group 48th hour, HTT-24: Head and Thoracic Trauma Group 24th hour, HTT-48: Head and Thoracic Trauma 48th hour.) The incidence of bacterial translocation in the 24th HTT group was significantly higher than that of all other groups $(p<0.05)$. Although the rate of bacterial translocation in the 24th TT group was higher than that of the $\mathrm{C}$ and $\mathrm{HT}$ groups, this difference was not statistically significant.

lymph nodes) without any growth in the lungs was accepted as a positive sign of BT. BT was found in 7 rats in the 24 th hour HTT group (70\%), in 4 rats of the 24 th hour TT group (40\%) and in 2 rats in each the 24th hour $C$ and 24th hour HT groups ( $17 \%$ each). All of the blood cultures remained sterile. No significant difference was found in the cultures of the control group and trauma groups at 48 hours (Figure 2).

The isolated bacteria were E. coli $(90 \%)$, Enterococci $(7 \%)$ and Staphylococci (3\%). As the indigenous flora of the intestines includes enterococci and staphylococci as well as E. coli, their growth in harvested tissue cultures was accepted as a sign of BT as well.

The incidence of BT in the 24th hour HTT group was significantly higher than that of all other groups $(p<0.05)$. Although the rate of bacterial translocation in 24 th hour TT group was

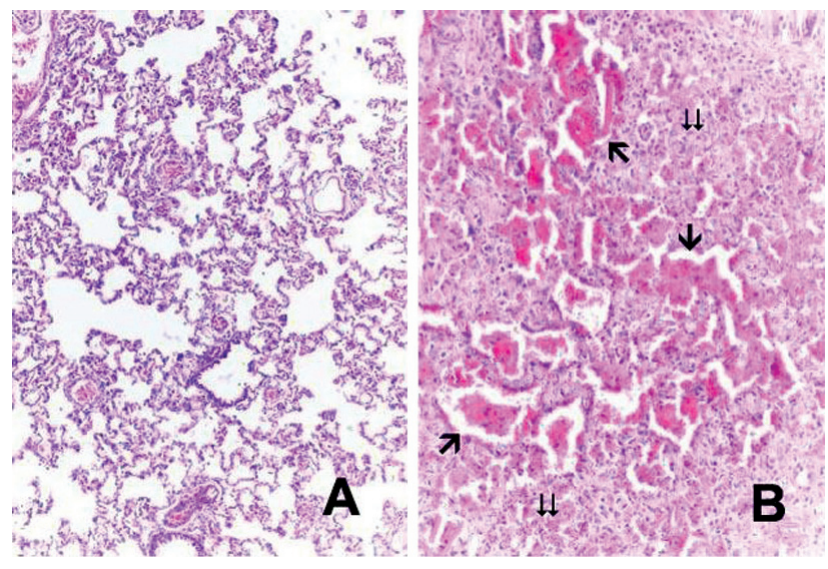

Figure 3. Light microscopy of lung tissue (HEx100). (a) Normal lung parenchyma in the control group. (b) Diffuse inflammatory cell infiltration (double arrows) and alveolar hemorrhage (arrows) are seen in lung parenchyma in the HTT group.

higher than that of the $\mathrm{C}$ and HT groups, this difference was not statistically significant.

\section{Light Microscopy}

Light microscopic evaluation of hematoxylin and eosin stained slides revealed almost normal morphology in the $\mathrm{C}$ group. In contrast, the HT group had mild to moderate lung injury at both 24 and 48 hours. In the TT and HTT groups, moderate to severe injury was recorded at both 24 and 48 hours (Figure $3 \mathrm{a}, \mathrm{b}$ ). The light microscopy score of the HTT group was significantly different than those of the $\mathrm{C}$ and HT groups at 24 and 48 hours $(p<0.05)$. The other groups were not significantly different (Table 2).

\section{Apoptosis (TUNNEL)}

The number of TUNNEL positive stained nuclei in the lung tissue for each group is presented in Figure 4.

The control group had only a few TUNNEL positive stained nuclei (alveolar epithelial, endothelial). The number of TUNNEL positive stained nuclei was increased in the TT, HT, and HTT groups at 24 and 48 hours (Figure 5a, b).

There was a significantly higher number of TUNNEL stained nuclei in the HTT group than in the C group 24 hours follow-

Table 2. Correlations of the serum cytokine levels, bacterial growth and apoptosis

\begin{tabular}{|c|c|c|c|c|c|c|c|c|c|c|}
\hline \multirow[b]{2}{*}{ Injury level } & \multicolumn{3}{|c|}{ Control groups (n) } & \multicolumn{2}{|c|}{ TT groups $(n)$} & \multicolumn{2}{|c|}{ HT groups (n) } & \multicolumn{2}{|c|}{ HTT groups $(n)$} & \multirow[t]{2}{*}{ Total (n) } \\
\hline & $0^{\text {th }}$ hour & $24^{\text {th }}$ hour & $48^{\text {th }}$ hour & $24^{\text {th }}$ hour & $48^{\text {th }}$ hour & $24^{\text {th }}$ hour & $48^{\text {th }}$ hour & $24^{\text {th }}$ hour & $48^{\text {th }}$ hour & \\
\hline Severe & 0 & 0 & 0 & 4 & 6 & 0 & 0 & 5 & 9 & 24 \\
\hline Moderate & 0 & 0 & 0 & 3 & 3 & 5 & 0 & 4 & 1 & 16 \\
\hline Minimaly & 0 & 0 & 0 & 3 & I & 3 & 5 & I & 0 & 13 \\
\hline No injury & 10 & 10 & 10 & 0 & 0 & 2 & 5 & 0 & 0 & 37 \\
\hline Total & 10 & 10 & 10 & 10 & 10 & 10 & 10 & 10 & 10 & 90 \\
\hline
\end{tabular}

C: Control; HT: Head trauma; TT: Thoracic trauma; HTT: Head and thoracic trauma. 


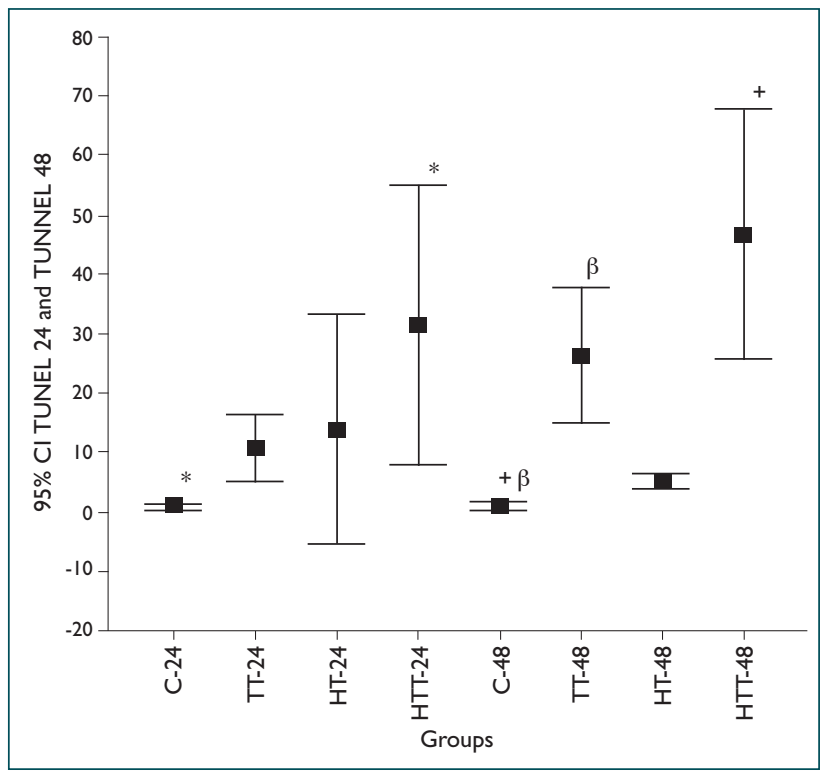

Figure 4. Lung tissue apoptotic cell numbers. Error bars represent $95 \%$ confidence intervals of the means $(95 \% \mathrm{Cl})$. In the HTT-24 group, lung tissue apoptotic cell numbers were elevated when compared with the C-24 group ( $\left.{ }^{*} \mathrm{p}<0.05\right)$. In the HTT-48 group, lung tissue apoptotic cell numbers were elevated when compared with the C-48 group $(+p<0.001)$. In the TT-48 group, lung tissue apoptotic cell numbers were elevated when compared with the C-48 group $(\beta \mathrm{p}<0.01)$. (C-24: Control Group 24th hour, C-48: Control Group 48th hour, HT-24: Head Trauma Group 24th hour, HT-48: Head Trauma Group 48th hour, TT-24: Thoracic Trauma Group 24hth hour, TT48: Thoracic Trauma Group 48th hour, HTT-24: Head and Thoracic Trauma Group 24th hour, HTT-48: Head and Thoracic Trauma 48th hour.)

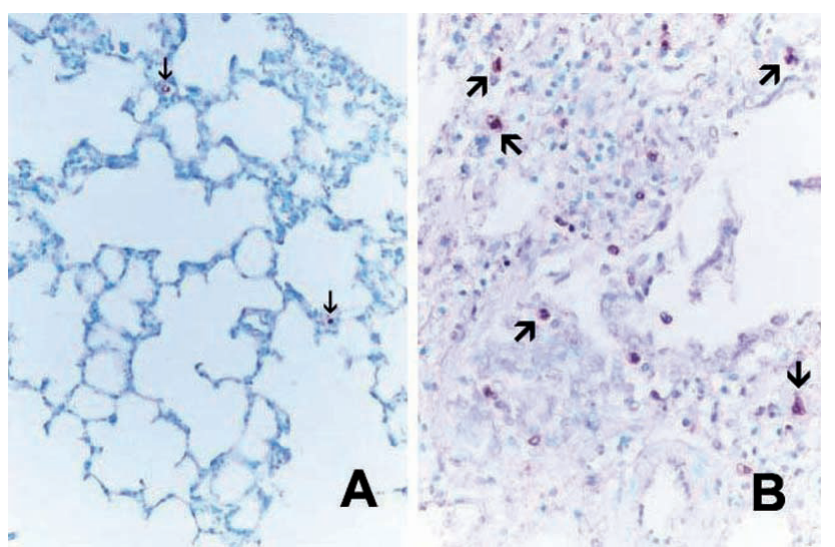

Figure 5. TUNNEL staining of lung tissue (X200). (a) Very rare TUNNEL positive cells in the control group. (b) Widespread TUNNEL positive alveolar epithelium and stromal cells (arrows) are seen in the HTT group.

ing trauma $(p<0.05)$. The TT and HTT groups were significantly higher than the $\mathrm{C}$ and $\mathrm{HT}$ groups at 48 hours $(\mathrm{p}<0.05)$. (Figure 5a, b).

\section{Correlations}

Correlations were calculated between inflammatory responses and bacterial translocation, and these results are presented in Table 3. There were highly significant correlations
Table 3. Correlations of the serum cytokine levels, bacterial growth and apoptosis

\begin{tabular}{cccc}
\hline \multicolumn{2}{c}{ Parameters } & $\mathbf{R}$ & Statistical significance \\
\hline MCP-I & IL-I $\beta$ & 0.924 & $\mathrm{P}<0.00$ I \\
MCP-I & IL-4 & 0.924 & $\mathrm{P}<0.00$ I \\
IL-I $\beta$ & IL-4 & 0.923 & $\mathrm{P}<0.00$ I \\
IL-4 & Tunnel & 0.914 & $\mathrm{P}<0.00$ I \\
MCP-I & TNF- $\alpha$ & 0.889 & $\mathrm{P}<0.00$ I \\
IL-I $\beta$ & TNF- $\alpha$ & 0.878 & $\mathrm{P}<0.00$ I \\
IL-I $\beta$ & Tunnel & 0.863 & $\mathrm{P}<0.0$ I \\
IL-I0 & Tunnel & 0.836 & $\mathrm{P}<0.01$ \\
IL-4 & TNF- $\alpha$ & 0.781 & $\mathrm{P}<0.01$ \\
IL-I0 & TNF- $\alpha$ & 0.749 & $\mathrm{P}<0.05$ \\
IL-I $\beta$ & IL-I0 & 0.730 & $\mathrm{P}<0.05$ \\
IL-4 & IL-I0 & 0.714 & $\mathrm{P}<0.05$ \\
TNF- $\alpha$ & Tunnel & 0.691 & $\mathrm{P}<0.05$ \\
MCP-I & Tunnel & 0.687 & $\mathrm{P}<0.05$ \\
TNF- $\alpha$ & Growth & 0.592 & n.s. \\
Growth & Tunnel & 0.533 & n.s. \\
MCP-I & IL-I0 & 0.529 & n.s. \\
IL-I $\beta$ & Growth & 0.511 & n.s. \\
IL-I0 & Growth & 0.459 & n.s. \\
MCP-I & Growth & 0.401 & n.s. \\
IL-4 & Growth & 0.363 & n.s. \\
\hline
\end{tabular}

R: Correlation coefficient; n.s.: Not statistically significant; MCP-I: Monocyte chemoattractant protein-I; IL-I $\beta$ : Interleukin-I; IL-4: Interleukin-4; IL10: Interleukin-10; TNF- $\alpha$ : Tumor necrosis factor alpha.

between IL-I $\beta$ and MCP-I, IL-I $\beta$ and IL-4, IL-I $\beta$ and TNF- $\alpha$, IL-4 and MCP-I, IL-4 and TUNNEL, and TNF- $\alpha$ and MCP-I $(p<0.00 \mathrm{I})$. Significant correlations were observed between IL- 4 and TNF- $\alpha$, IL- I $\beta$ and TUNNEL, and IL- I 0 and TUNNEL $(p<0.0 I)$. The correlations between IL-I0 and IL-I $\beta$, IL-I0 and TNF- $\alpha$, IL- 10 and IL-4, TNF- $\alpha$ and TUNNEL, and MCP-I and TUNNEL were also significant, but not as significant as the aforementioned correlations $(p<0.05)$.

\section{DISCUSSION}

Two-thirds of the patients who die of complications that develop following a major trauma have single or multiple organ failure, of which the most commonly encountered is pulmonary dysfunction. ${ }^{[1,3,15]}$ Previous studies have reported that the first organ to fail after trauma is the respiratory system, which serves as a pacemaker in the development of MOF ${ }^{[1]}$ It has been noted in a clinical study that if patients with head trauma also had lung injury, a significant increase was seen in their morbidity, length of hospital stay and mortality. ${ }^{[16]}$ Recent studies have focused on systemic inflammatory processes, immunologic mechanisms, controlling inflammatory responses and improving immunomodulator procedures that reinforce the body's defense. Our objective in this study is to contribute to research on systemic inflammatory responses that arise in traumas, histopathologic changes that occur in pulmonary tissue, apoptosis and bacterial translocation, and the correlations between these processes. In general, our results showed that IL-IB and MCP-I increased significantly 
in all trauma groups (HTT, TT and HT groups) in comparison to the control group. Additionally, IL- I0, IL-4 and TNF- $\alpha$ were significantly elevated in all HTT groups. IL-I0, IL-4 and TNF- $\alpha$ levels were higher in some HT groups and lower in TT groups at different time points, while they were higher in TT groups and lower in HT groups at other times. However, in general, the values in the HT and TT groups were significantly higher than those of the $\mathrm{C}$ group. Since IL- 10 was significantly higher in the TT and HTT groups at both 24 and 48 hours and since there was not any significant difference in IL- 10 between these groups, we can hypothesize that there is a correlation between thoracic trauma and IL- I0 levels. Similarly, since there was a significant difference in TNF- $\alpha$ levels in the TT and HTT groups and the HT group, we hypothesize that there is a correlation between thoracic trauma and TNF- $\alpha$.

There were significant correlations between all of the measured cytokine levels; in particular, the correlations between MCP-I and IL-I 13 with other cytokines were the strongest. The correlations of MCP-I with other cytokines were also significant, but the correlation coefficients were lower. TNF- $\alpha$ was correlated with all cytokines, but levels of significance were variable. TUNNEL is an indication of apoptosis that was significantly correlated with cytokines. On the other hand, bacterial growth, which is an indicator of bacterial translocation, was not significantly correlated with cytokine levels and TUNNEL results.

Experimental models of blunt thoracic trauma have shown that a severe inflammatory response develops during the first 24-48 hours, but normal levels are restored at 72 hours. This data suggests that additional processes should be investigated in order to clarify lung injury and causes of morbidity. [3-5] These studies also reported that TNF- $\alpha$ and IL-I I were primary mediators in the activation of other cytokines, and ensured prostaglandin release, synthesis of pro-coagulant factors and activation of leukocyte chemotaxis with adhesion molecules like ICAM and E-selectin. Accumulation of neutrophils increases the production and release of vasoactive substances (leukotrienes, eicosanoids, platelet-activating factor) and proteolytic enzymes (elastase, cathepsin G). All of these substances have been reported to cause injury to the endothelial layer and neighboring tissues. ${ }^{[16]}$ Previous studies have reported a correlation between TNF- $\alpha$ and apoptosis. Furthermore, in the early post-traumatic period, TNF- $\alpha$, IL$I B$ and MCP-I values showed an increase parallel to the increase in local and systemic neutrophil accumulation, and that the former peaked especially in the first 24 hours. ${ }^{[17-19]}$ Sato et al. ${ }^{[17]}$ reported that there were significantly lower TNF- $\alpha$ and IL-I I levels in a trauma group treated with a potent inhibitor of TNF- $\alpha$ and IL- I $\beta$ production, FR I67653, relative to the untreated trauma group. The correlation between these values and blood gas values may indicate that TNF- $\alpha$ and IL-I $\beta$ play a role in post-traumatic acute lung injury. In the current study, we found that although IL-IB and MCP-I values increased in all trauma groups at 24 and 48 hours, IL-I $B$ values in the HTT group at 48 hours were significantly higher than those in the HT and TT groups. We established that TNF- $\alpha$ values in the HTT and TT groups at 24 and 48 hours were significantly higher than those of the control group. However, the 24 hour TNF- $\alpha$ values in the HT group were the same as those of the $\mathrm{C}$ group, which peaked at 48 hours. Even though our results are consistent with those of the literature, the significantly higher levels of IL-I $B$ in the HTT group relative to the other trauma groups may be interpreted in relation with the cumulative effect of multiple traumas.

Many studies have been conducted regarding the relationship between trauma and IL-10, but the results differ widely, especially in evaluations of the lung. ${ }^{[20]}$ Turina et al. ${ }^{[15]}$ stressed that IL- 10 levels in BALF increased in the early post-traumatic period of patients with severe trauma, and that this increase resulted in alveolar neutrophil apoptosis. It has also been reported that anti-IL-10 treatment reduced apoptosis in patients with post-traumatic pulmonary dysfunction. ${ }^{[15]}$ On the contrary, Raghavedran et al. ${ }^{[3]}$ showed in their experimental thoracic trauma model that levels of IL- 10 in BALF did not significantly increase. Murphy et al. ${ }^{[2]}$ on the other hand, reported a significant increase in IL- 10 levels in the blood of trauma patients. Previous in vitro studies reported that there might be differences in the cytokine production of immune system cells stimulated by nitrogen. Likewise, conservative mutations in the areas where cytokines are coded, as well as nucleotide changes in the regulatory area might cause the differences in cytokine production. These genetic polymorphisms have been shown to affect cytokine release in both in vivo and in vitro media. ${ }^{[22,23]}$ Contradictory results have been obtained in similar trauma groups, and therefore, results of further studies aiming to clarify the relationships and correlations between thoracic trauma, multiple trauma and IL- I0 will be important. ${ }^{[24]}$ In the present study, we found that serum IL-IO values in the HTT and TT groups were significantly higher than those in the $\mathrm{C}$ and HT groups at 24 and 48 hours. However, there was no significant increase in the HT group relative to the $\mathrm{C}$ group. In addition, the development of apoptosis, which has been reported to peak at 48 hours, was significantly higher in the HTT and TT groups at 48 hours than in the $C$ and HT groups. Our current results indicate that there is a direct relationship between IL- 10 increase, apoptosis and acute lung injury.

Clinical and experimental studies have shown that apoptosis develops within 48 hours following trauma. Post-traumatic systemic inflammatory responses and toxic metabolites released from the neutrophils due to increased neutrophil accumulation is the first step of apoptosis formation. ${ }^{[5,15]}$ Ward et al. ${ }^{[25]}$ reported that IL-IO inhibited the activation of the extracellular signal-related kinase (ERK) pathway in purified human neutrophils, and that the inhibition of ERK eliminated the inhibitor effect on Caspase 8, thereby enabling more apoptosis, which was influenced by PMN. In our study, we established that significantly more apoptosis developed in the HTT and TT groups than in the HT and C groups at 48 hours. 
It has been reported that the respiratory system (28\%) was among the leading infection foci in patients with multiple traumas, and that the most commonly reproduced microorganisms were bacteria of the gastrointestinal flora like $S$. aureus (19-20\%), E. coli (18\%), Pseudomonas (10\%) and Enterococci $(9 \%) .{ }^{[2,26]}$ In our study, we determined that the reproduced bacteria were E. coli (90\%), Enterococci $(7 \%)$ and Staphylococci $(3 \%)$. The major cause of the death of patients undergoing multiple traumas has been shown to be MOF, the pathogenesis of which sepsis and pulmonary dysfunction are the most commonly blamed factors. Previous studies have shown that bacterial translocation developed in patients who had abdominal trauma, hemorrhage and burn. ${ }^{[7-9]}$ In one of our previous studies, we reported the development of bacterial translocation in multiple traumas, including thoracic trauma. ${ }^{[27]}$ In the same study, our results indicated that bacterial translocation developed in some cases of isolated thoracic trauma, although it was not statistically significant. In the present study, we found that bacterial translocation did not occur in the HT group, was extremely high in the TT group, but was only significantly higher in the HTT group, relative to other groups. In consideration of the quantitative measure of bacterial translocation in the TT group, we believe that thoracic trauma may significantly affect the development of bacterial translocation.

In our examination of the literature, we found that research generally included patients with severe multiple traumas, and that the number of studies aimed at patients with isolated thoracic trauma was insufficient.

As a result of our study, we found that multiple and/or thoracic trauma can trigger inflammatory and anti-inflammatory cascades. Based on our results, we believe that inflammatory mediators stemming from the lungs are the major cause of these triggers. In conclusion, thoracic trauma plays a major role in critical inflammation, bacterial translocation and tissue damage following multiple traumas.

\section{Conflict of interest: None declared.}

\section{REFERENCES}

1. Laudi S, Donaubauer B, Busch T, Kerner T, Bercker S, Bail H, et al. Low incidence of multiple organ failure after major trauma. Injury 2007;38:1052-8.

2. Lazarus HM, Fox J, Burke JP, Lloyd JF, Snow GL, Mehta RR, et al. Trauma patient hospital-associated infections: risks and outcomes. J Trauma 2005;59:188-94.

3. Raghavendran K, Davidson BA, Woytash JA, Helinski JD, Marschke CJ, Manderscheid PA, et al. The evolution of isolated bilateral lung contusion from blunt chest trauma in rats: cellular and cytokine responses. Shock 2005;24:132-8.

4. Raghavendran K, Davidson BA, Helinski JD, Marschke CJ, Manderscheid P, Woytash JA, et al. A rat model for isolated bilateral lung contusion from blunt chest trauma. Anesth Analg 2005;101:1482-9.

5. Liener UC, Knöferl MW, Sträter J, Barth TF, Pauser EM, Nüssler
AK, et al. Induction of apoptosis following blunt chest trauma. Shock 2003;20:511-6.

6. Wang ND, Stevens MH, Doty DB, Hammond EH. Blunt chest trauma: an experimental model for heart and lung contusion. J Trauma 2003;54:744-8.

7. Lichtman SM. Bacterial [correction of baterial] translocation in humans. J Pediatr Gastroenterol Nutr 2001;33:1-10.

8. Brathwaite CE, Ross SE, Nagele R, Mure AJ, O’Malley KF, García-Perez FA. Bacterial translocation occurs in humans after traumatic injury: evidence using immunofluorescence. J Trauma 1993;34:586-90.

9. Peitzman AB, Udekwu AO, Ochoa J, Smith S. Bacterial translocation in trauma patients. J Trauma 1991;31:1083-67.

10. Moore FA, Moore EE, Poggetti RS, Read RA. Postinjury shock and early bacteremia. A lethal combination. Arch Surg 1992;127:893-8.

11. Foda MA, Marmarou A. A new model of diffuse brain injury in rats. Part II: Morphological characterization. J Neurosurg 1994;80:301-13.

12. Baron EJ, Peterson LR, Finegold SM. Hospital epidemiology. In: Baron EJ, Peterson LR, Finegold SM, editors. Bailey and Scott's diagnostic microbiology. 9th ed. St. Louis: Mosby - Year Book; 1994. p. 284-95.

13. Steffen EK, Berg RD, Deitch EA. Comparison of translocation rates of various indigenous bacteria from the gastrointestinal tract to the mesenteric lymph node. J Infect Dis 1988;157:1032-8.

14. Koksel O, Cinel I, Tamer L, Cinel L, Ozdulger A, Kanik A, et al. N-acetylcysteine inhibits peroxynitrite-mediated damage in oleic acid-induced lung injury. Pulm Pharmacol Ther 2004;17:263-70.

15. Turina M, Hoth JJ, Turpen RM, Scott MJ, Cheadle WG. Alveolar interleukin-10 regulates neutrophil apoptosis in severely traumatized patients. J Trauma 2007;63:733-9.

16. Salim A, Martin M, Brown C, Inaba K, Browder T, Rhee P, et al. The presence of the adult respiratory distress syndrome does not worsen mortality or discharge disability in blunt trauma patients with severe traumatic brain injury. Injury 2008;39:30-5.

17. Sato H, Kasai K, Tanaka T, Kita T, Tanaka N. Role of tumor necrosis factor-alpha and interleukin-1beta on lung dysfunction following hemorrhagic shock in rats. Med Sci Monit 2008;14:BR79-87.

18. Toda Y, Takahashi T, Maeshima K, Shimizu H, Inoue K, Morimatsu H, et al. A neutrophil elastase inhibitor, sivelestat, ameliorates lung injury after hemorrhagic shock in rats. Int J Mol Med 2007;19:237-43.

19. Fujimi S, Ogura H, Tanaka H, Koh T, Hosotsubo H, Nakamori Y, et al. Increased production of leukocyte microparticles with enhanced expression of adhesion molecules from activated polymorphonuclear leukocytes in severely injured patients. J Trauma 2003;54:114-20.

20. Taniguchi T, Koido Y, Aiboshi J, Yamashita T, Suzaki S, Kurokawa A. The ratio of interleukin- 6 to interleukin-10 correlates with severity in patients with chest and abdominal trauma. Am J Emerg Med 1999;17:54851.

21. Murphy T, Paterson H, Rogers S, Mannick JA, Lederer JA. Use of intracellular cytokine staining and bacterial superantigen to document suppression of the adaptive immune system in injured patients. Ann Surg 2003;238:401-11.

22. Fishman D, Faulds G, Jeffery R, Mohamed-Ali V, Yudkin JS, Humphries S, et al. The effect of novel polymorphisms in the interleukin-6 (IL-6) gene on IL-6 transcription and plasma IL-6 levels, and an association with systemic-onset juvenile chronic arthritis. J Clin Invest 1998;102:136976 .

23. Awad MR, Webber S, Boyle G, Sturchioĉ C, Ahmed M, Martell J, et al. The effect of cytokine gene polymorphisms on pediatric heart allograft outcome. J Heart Lung Transplant 2001;20:625-30.

24. Batistaki C, Kostopanagiotou G, Myrianthefs P, Dimas C, Matsota P, 
Pandazi A, et al. Effect of exogenous catecholamines on tumor necrosis factor alpha, interleukin-6, interleukin-10 and beta-endorphin levels following severe trauma. Vascul Pharmacol 2008;48:85-91.

25. Ward C, Murray J, Clugston A, Dransfield I, Haslett C, Rossi AG. Interleukin-10 inhibits lipopolysaccharide-induced survival and extracellular signal-regulated kinase activation in human neutrophils. Eur J Immunol 2005;35:2728-37.
26. Papia G, McLellan BA, El-Helou P, Louie M, Rachlis A, Szalai JP, et al. Infection in hospitalized trauma patients: incidence, risk factors, and complications. J Trauma 1999;47:923-7.

27. Ayan E, Demir M, Akdağ A, Koksel O, Ersoz G, Ozdulger A. Bacterial translocation in thoracic and/or head trauma. Turkiye Klinikleri J Med Sci 2009;29:859-65.

\title{
DENEYSEL ÇALIŞMA - ÖZET
}

\section{Multipl travmayı takiben enflamatuvar yanıt, apopitozis ve bakteriyel translokasyonda torasik travmanın rolï}

\section{Dr. Erhan Ayan, ${ }^{1}$ Dr. Oğuz Köksel, ${ }^{1}$ Dr. Ayşe Polat, ${ }^{2}$ Dr. Lülüfer Tamer, ${ }^{3}$ Dr. Gülden Ersöz, ${ }^{4}$ Dr. Murat Demir, Dr. Hatice Yıldırım Yaroğlu, ${ }^{3}$ Dr. Alper Akdağ, ${ }^{4}$ Dr. Ali Özdülger, ${ }^{1}$ Dr. Sema Erden ${ }^{5}$}

\author{
${ }^{1}$ Mersin Üniversitesi Tıp Fakültesi Araştırma ve Uygulama Hastanesi, Göğüs Cerrahisi Anabilim Dalı, Mersin \\ ${ }^{2}$ Mersin Üniversitesi Tıp Fakültesi Araştırma ve Uygulama Hastanesi, Patoloji Anabilim Dalı, Mersin \\ ${ }^{3}$ Mersin Üniversitesi Tıp Fakültesi Araştırma ve Uygulama Hastanesi, Biokimya Anabilim Dalı, Mersin \\ ${ }^{4}$ Mersin Üniversitesi Tıp Fakültesi Araştırma ve Uygulama Hastanesi, Engeksiyon Hastalıkları Anabilim Dalı, Mersin
}

${ }^{5}$ Sağlık Meslek Lisesi, Biyoistatistik, Mersin

AMAÇ: Künt göğüs travması ve komplikasyonları acil servislerde karşılaşılan en yaygın klinik problemlerden biridir. Postkontüzyon pnömoninin patogenezi, akut akciğer hasarı, akut solunum yetersizliği sendromu ve diğer etkili faktörler ile enflamatuvar yanıt arasındaki ilişkisi konusunda araştırmalara ihtiyaç duyulmaktadır. Bu çalışmamızda çoklu travma modelinde enflamasyon, apopitozis ve bakteriyel translokasyonun gelişimini araştırdık. GEREÇ VE YÖNTEM: Doksan adet Wistar cinsi sıçanı dokuz gruba ayırdık; 24 ve 48. saat torasik travma (TT), 24 ve 48. saat kafa travması (HT), 24 ve 48. saat kafa ve toraks travması (HTT), 0.24 ve 48 saat kontrol grupları. Sıçanlara standart künt toraks ve/veya kafa travması uygulandı ve travma sonrası 24. ve 48. saatte sakrifiye edildi. Farklı organlardan alınan çoklu örnekler ve kan örnekleri toplandı ve aerobik organizmalar için kantitatif kültür yapıldı. Serumda interlökinler, MCP-I seviyeleri ve akciğerde apopitozis değerlendirildi.

BULGULAR: Kontrol grubu ile karşılaştıııldığında tüm travma gruplarında interlökin, TNF- $\alpha$, MCP-I sevileri anlamlı olarak yüksekti $(p=0.00 \mathrm{I})$. Kontrol grubu ile karşılaştıııldığında HTT grubunda apopitotik hücreler anlamlı olarak fazlaydı ( $p=0.009)$. Tüm grupların ışık mikroskopik değerlendirmesinde kontrol grubuna göre HTT grubunda belirgin artış vardı. Bakteriyel translokasyon HTT grubunda anlamlı biçimde yüksekti ( $p=0.003)$. TARTIŞMA: Künt toraks travmasının olduğu çoklu travmalarda çok sayıda enflamauvar mediatör artmakta ve bakteriyel translokasyon ve apopitotik proçesi etkilemektedirler. Travma ile ilişkili enflamasyon ve enfeksiyonlar arasındaki ilişkinin anlaşımasının komplike hastaları tedavi yaklaşımlarında etkili olacağına inanıyoruz.

Anahtar sözcükler: Apopitozis; bakteriyel translokasyon; göğüs travması; interlökin; sistemik enflamatuvar yanıt sendromu; çoklu travma.

Ulus Travma Acil Cerr Derg 2013;19(6):49I-499 doi: 10.5505/tjtes.2013.29660 